Laporan Penelitian

\title{
Hubungan ekspresi RANKL dengan derajat destruksi tulang akibat kolesteatoma pada otitis media supuratif kronik
}

\author{
Lilia Yarisman*, Harry Agustaf Asroel*, Askaroellah Aboet*, Fotarisman Zaluchu** \\ *Departemen Telinga Hidung Tenggorok - Bedah Kepala Leher \\ Fakultas Kedokteran Universitas Sumatera Utara/ \\ Rumah Sakit Umum Pusat Haji Adam Malik \\ **Fakultas Ilmu Kesehatan Masyarakat Universitas Sumatera Utara \\ Medan
}

\begin{abstract}
ABSTRAK
Latar belakang: Otitis media supuratif kronik (OMSK) dengan kolesteatoma merupakan penyakit pada telinga tengah dengan salah satu komplikasi berupa destruksi tulang, yang dapat menyebabkan kematian. Receptor Activator of Nuclear Factor K $\beta$-Ligand (RANKL) merupakan salah satu sitokin yang berperan dalam proses destruksi tulang. Tujuan: Mengetahui hubungan ekspresi RANKL dengan derajat destruksi tulang akibat kolesteatoma pada penderita OMSK tipe bahaya. Metode: Penelitian ini bersifat analitik dengan desain cross sectional. Sebanyak 40 sampel kolesteatoma dilakukan pemeriksaan imunohistokimia untuk dinilai ekspresi RANKL pada kolesteatoma. Hasil: Terdapat hubungan yang signifikan antara ekspresi RANKL dengan derajat destruksi tulang dan komplikasi yang terjadi $(p<0,05)$. Tidak terdapat hubungan antara ekspresi RANKL dengan kelompok umur dan jenis kelamin ( $>0,05)$. Kesimpulan: Terdapat hubungan yang signifikan antara derajat destruksi tulang dengan ekspresi RANKL melalui pemeriksaan imunohistokimia.
\end{abstract}

Kata kunci: RANKL, destruksi tulang, kolesteatoma, OMSK

\section{ABSTRACT}

Background: Chronic suppurative otitis media (CSOM) with cholesteatoma is a middle ear disease, leading to bone structure destruction which can cause fatal case. Receptor Activator of Nuclear Factor KR-Ligand (RANKL) is known as one of the cytokine that has important role in the process of bone destruction. Purpose: To identify an association between RANKL expression with bone destruction level due to cholesteatoma in malignant CSOM patients. Method: This was an analytical study with cross sectional design. About 40 cholesteatoma sample was examinated by using immunohistochemistry to measure its RANKL expression. Result: There was a significant relationship $(p<0.05)$ between $R A N K L$ expression with bone destruction level and complication. There was no significant relationship between $R A N K L$ expression with age and sex ( $p>0.05)$. Conclusion: There was a significant relationship between bone destruction level with the RANKL expression by immunohistochemistry examination.

Keywords: RANKL, bone destruction, cholesteatoma, CSOM

Alamat korespondensi : Dr. Lilia Yarisman. Departemen Telinga Hidung Tenggorok Bedah Kepala Leher Fakultas Kedokteran Universitas Sumatera Utara, Rumah Sakit Umum Pusat Haji Adam Malik Medan. Jalan Bunga Lau no. 17 Medan. Email: lilia_yarisman@yahoo.co.id. 


\section{PENDAHULUAN}

Otitis media supuratif kronik (OMSK) atau disebut dengan radang kronis telinga tengah dapat menyebabkan komplikasi ekstrakranial dan intrakranial, sehingga bisa meningkatkan angka morbiditas yang cukup tinggi. ${ }^{1}$ Pada negara berkembang, banyak faktor yang memengaruhi terjadinya penyakit OMSK ini di antaranya ialah kemiskinan, rendahnya pengetahuan masyarakat, kurangnya tenaga spesialis, serta keterbatasan pelayanan kesehatan, dapat memperburuk kondisi penderita dan komplikasi OMSK. Faktor risiko OMSK adalah lingkungan yang padat, higiene yang buruk, nutrisi yang kurang, tingginya koloni bakteri patogen di nasofaring, dan kurangnya fasilitas pelayanan kesehatan. ${ }^{2}$

World Health Organization (WHO) ${ }^{3}$ menyebutkan bahwa penderita OMSK di seluruh dunia berkisar antara 65-330 juta orang, dengan $94 \%$ berada di negara berkembang. Sebanyak 60\% (39-200 juta) mengalami kematian, dan sekitar 2 juta mengalami kecacatan.

Secara umum, prevalensi OMSK di negara berkembang seperti India dan Myanmar dilaporkan lebih tinggi yaitu $5,2 \%$ dan $6 \%$. Angka prevalensi OMSK di Indonesia dilaporkan sebesar 3,6\%. ${ }^{3}$ Hal serupa juga ditemukan di Poliklinik Telinga Hidung Tenggorok Rumah Sakit Dr. Moewardi Surakarta pada tahun 2008, yaitu terdapat 21 kasus OMSK tipe bahaya dari 296 pasien. ${ }^{4}$ Sementara itu, di Rumah Sakit Dr. Saiful Anwar Malang ditemukan kasus baru OMSK tipe bahaya sebanyak 25 penderita pada tahun 2009 dan 38 penderita pada tahun $2010 .{ }^{5}$ Siregar ${ }^{6}$ menemukan di Sumatera Utara, sebanyak 119 pasien OMSK dengan kolesteatoma yang berobat ke Departemen Telinga Hidung Tenggorok - Bedah Kepala Leher (THT-KL) Rumah Sakit Haji Adam Malik Medan selama 1 Januari 2006 - 31 Desember 2010.
OMSK dibagi menjadi 2 tipe, yaitu tipe jinak atau tanpa kolesteatoma, dan tipe bahaya atau dengan kolesteatoma. ${ }^{7,8}$ Kolesteatoma merupakan kelainan hiperproliferasi yang dihubungkan dengan terjadinya inflamasi kronis dan destruksi tulang. Karakteristik dari kolesteatoma telinga tengah adalah kemampuannya yang dapat mendestruksi tulang. Erosi tulang yang disebabkan kolesteatoma ini merupakan penyebab penting morbiditas dan mortalitas pada penderita otitis media kronis. ${ }^{9}$ Secara klinis diketahui bahwa kondisi infeksi serta inflamasi akan memfasilitasi pertumbuhan kolesteatoma telinga tengah, serta absorpsi tulang. Pengobatan OMSK dengan kolesteatoma saat ini adalah pembedahan. ${ }^{10} \mathrm{Hal}$ ini menyebabkan penatalaksanaan kolesteatoma menjadi sangat mahal dan teknik operasinya sulit dikerjakan di negara yang miskin. ${ }^{3}$

Mekanisme destruksi tulang pada kolestetaoma merupakan hal yang penting untuk diketahui, sebab komplikasi yang diakibatkan dari kemampuan destruksi tulang tersebut merupakan hal yang sangat berbahaya. ${ }^{8}$

Osteoklas dan oesteoblas memegang peranan penting dalam hal meningkatnya kemampuan destruksi tulang. Receptor Activator of Nuclear Factor K $\beta$-Ligand (RANKL) diketahui memiliki peranan penting dari mekanisme destruksi tulang pada sejumlah penyakit terutama yang terdapat pada kolesteaoma. Pengenalan RANKL oleh ekspresi Receptor Activator of Nuclear Factor K $\beta$ (RANK) dari membran sel osteoklas juga memfasilitasi destruksi tulang. Sejumlah sitokin dan growth factor akan dilepaskan pada proses diferensiasi osteoklas, yang akan merangsang destruksi tulang, sehingga aktivitas proliferasi meningkat. Selain itu, RANKL juga memegang peranan penting dalam hal diferensiasi osteoblas yang dapat berikatan dengan reseptor RANK sehingga dapat menginduksi diferensiasi dari osteoklas. 
Meningkatnya osteoklas menjadikan absorbsi tulang juga meningkat, sehingga destruksi tulang juga dapat meningkat. Selain itu, timbulnya kolesteatoma juga diakibatkan oleh peningkatan lipopolisakarida yang terdapat pada kuman gram negatif, sehingga dapat meningkatkan ekspresi RANKL dan juga meningkatkan destruksi tulang. ${ }^{8,11,12}$

Terjadinya destruksi tulang dipicu oleh overekspresi RANKL, tidak hanya pada kolesteatoma, namun juga sering ditemukan pada penyakit rheumatoid arthritis, osteoporosis, penyakit periodontal, dan lain-lain. Penelitian ini menekankan ekspresi RANKL pada kolesteatoma, seperti pada beberapa penelitian lain. Chung $^{13}$ menyebutkan bahwa terjadi overekspresi dari RANKL dan terjadi peningkatan rasio RANKL pada kolesteatoma yang berhubungan dengan destruksi tulang. Miyasato $^{12}$ di Jepang menemukan terjadi peningkatan ekspresi RANKL pada kolesteatoma telinga tengah. Kuczkowski ${ }^{14}$ menyebutkan bahwa ekspresi RANKL pada jaringan kolesteatoma memegang peranan penting pada patogenesis terbentuknya kolesteatoma. Jeong $\mathrm{dkk}^{15}$ menemukan dari 22 kasus kolesteatoma dan 5 kasus kulit liang telinga luar, ditemukan sebanyak $87,41 \pm 19,1$ ekspresi RANKL pada sel yang positif pada kolesteatoma, dan 41,6 $\pm 11,1$ pada kulit liang telinga luar. Ekspresi RANKL meningkat pada pada kolesteatoma, dibandingkan dengan kulit liang telinga luar.

Penelitian ini bertujuan untuk lebih memahami dan menganalisa sifat kolestetaoma pada penderita OMSK tipe bahaya melalui ekspresi RANKL, sehingga dapat dilakukan tatalaksana tepat dan mencegah terjadinya rekurensi. Selama ini, penelitian ataupun literatur mengenai ekspresi RANKL dari kolesteatoma pada penderita OMSK tipe bahaya di Indonesia masih belum banyak dilakukan, sehingga peneliti tertarik melakukan penelitian mengenai ekspresi RANKL pada kolestetaoma, pada penderita OMSK tipe bahaya di Rumah Sakit Umum Pusat Haji Adam Malik Medan.

\section{METODE}

Penelitian ini bersifat analitik dengan desain cross sectional yang dilakukan di Poliklinik Departemen Telinga Hidung Tenggorok Bedah Kepala - Leher (THT-KL) Fakultas Kedokteran Universitas Sumatera Utara (FK USU) Rumah Sakit Umum Pusat (RSUP) Haji Adam Malik Medan. Pemeriksaan imunohistokimia dilakukan di Departemen Patologi Anatomi RSUP. H. Adam Malik Medan.

Populasi penelitian ini merupakan seluruh penderita dengan diagnosis OMSK tipe bahaya, dengan besar sampel sebanyak 40 kasus. Sampel yang diambil harus memenuhi kriteria inklusi dan eksklusi dari penelitian. Kriteria inklusi berupa kolesteatoma penderita OMSK tipe bahaya yang diambil dari tindakan operasi mastoidektomi. Kriteria eksklusi berupa kolesteatoma yang tidak dapat dilakukan pemeriksaan histopatologi atau imunohistokimia karena tidak representatif atau rusak.

Setelah jumlah sampel terpenuhi maka dilakukan pemeriksaan ekspresi RANKL dengan pewarnaan imunohistokimia. Selain itu, dilakukan penilaian imunoreaktivitas RANKL yaitu dengan mengalikan hasil skor luas dengan skor intensitas, sehingga diperoleh skor imunoreaktif RANKL. Skor luas terdiri dari 3 kategori, di mana kategori pertama yaitu $10 \%$, kategori kedua yaitu $11-50 \%$ dilanjutkan dengan kategori ketiga yaitu 51-100\%. Setelah dilihat pewarnaannya, kemudian diperoleh skor intensitas yang terbagi dalam tiga kategori, yaitu pewarnaannya lemah, sedang, atau kuat. Setelah masing-masing skor dikalikan yaitu skor luas dengan skor intensitas, maka diperoleh skor imunoreaktivitas RANKL. Hasil dari perkalian tersebut dikategorikan 
menjadi tiga kategori yaitu jika hasil yang diperoleh bernilai 1-3 termasuk kategori yang lemah, 4-6 adalah kategori yang sedang, dan untuk kategori yang kuat yaitu jika memperoleh nilai maksimum 9. Jika skor imunoreaktivitas RANKL yang diperoleh tersebut ada di kategori lemah maka disebut dengan positif lemah, jika kategorinya sedang maka dapat dikatakan bahwa skor imunoreaktivitas RANKL adalah positif sedang, dan sama halnya dengan positif kuat bila kategorinya adalah yang kuat.

\section{HASIL}

Didapati jumlah subyek penelitian sebanyak 40 sampel. Diketahui 57,5\% sampel berjenis kelamin laki-laki dan $42,5 \%$ berjenis kelamin perempuan. Berdasarkan kelompok usia, diketahui bahwa frekuensi tertinggi penderita OMSK tipe bahaya adalah pada kelompok usia 0-20 tahun yaitu sebanyak 19 penderita $(47,5 \%)$. Sebaliknya frekuensi yang terendah adalah pada kelompok umur $>60$ tahun sebanyak 2 penderita $(5 \%)$, diikuti dengan urutan kedua tertinggi pada kelompok umur 21-40 tahun $(27,5 \%)$, selanjutnya pada kelompok umur 41-60 tahun (20\%).

Jika dilihat dari ketegori lama keluhan menderita OMSK tipe bahaya, didapati sebanyak 17 sampel (42,5\%) adalah penderita dengan durasi penyakit 6-10 tahun. Sebaliknya frekuensi yang paling sedikit adalah penderita OMSK tipe bahaya dengan durasi 0-5 tahun yaitu sebanyak 10 sampel $(25 \%)$.

Diperoleh gejala klinis yang paling banyak dijumpai yaitu telinga berair dan gangguan pendengaran (100\%), bengkak di belakang telinga sebanyak 10 sampel (9,01\%), lubang di belakang telinga sebanyak 8 sampel (7,20\%), mulut mencong sebanyak 7 sampel $(6,31 \%)$, sakit kepala sebanyak 5 sampel $(4,5 \%)$, dan hoyong sebanyak 1 sampel $(0,9 \%)$.

Sementara itu, untuk komplikasi yang paling sering dijumpai adalah abses retroaurikula sebanyak 10 sampel $(32,26 \%)$, dan komplikasi yang paling sedikit terjadi adalah abses otak sebanyak 1 sampel $(3,23 \%)$. Selain dua komplikasi tersebut terdapat juga komplikasi lain yaitu fistel retroaurikula sebanyak 8 sampel $(25,80 \%)$, paresis nervus fasialis 7 sampel $(22,58 \%)$, dan labirinitis 5 sampel $(16,13 \%)$.

Pada penelitian ini diperoleh ekspresi yang positif lemah sebanyak 5 sampel $(12,5 \%)$, positif sedang 20 sampel $(50 \%)$, dan positif kuat sebanyak 15 sampel (37,5\%). Derajat destruksi tulang pada responden dijumpai kategori ringan sebanyak 4 sampel (10\%), kategori sedang 24 sampel (60\%), dan kategori berat sebanyak 12 sampel (30\%). Hasil gambaran yang diperoleh dari pemeriksaan ekspresi RANKL dapat dilihat pada gambar 1.

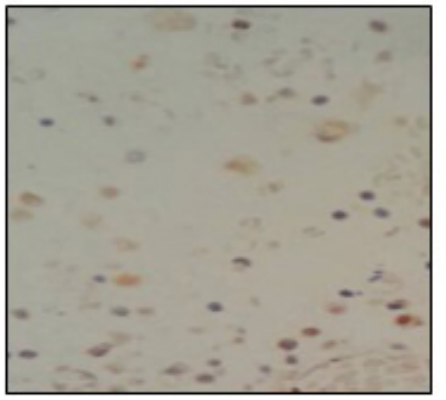

(a)

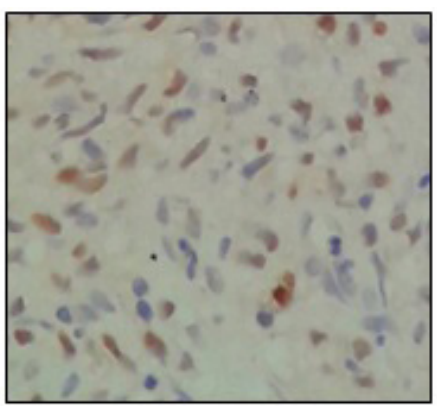

(b)

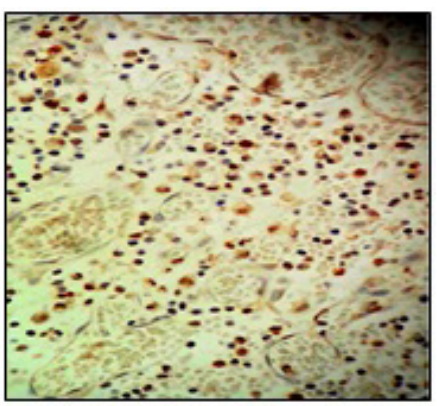

(c)

Gambar 1. Ekspresi RANKL: a) Ekspresi RANKL positif lemah, b) Ekspresi RANKL positif sedang, c) Ekspresi RANKL positif kuat. 
Gambar 2 menjelaskan proporsi ekspresi RANKL yang dihubungkan dengan derajat destruksi tulang pada penderita OMSK. Setelah dilakukan uji statistik, diperoleh hubungan signifikan antara ekspresi RANKL dengan derajat destruksi tulang, di mana $p$ $<0,05$. Hasil tersebut menunjukkan bahwa semakin kuat ekspresi RANKL maka derajat destruksi tulang dari kolesteatoma yang diperiksa akan semakin berat.

Proporsi ekspresi RANKL dihubungkan dengan komplikasi yang dijumpai terlihat pada gambar 3. Diperoleh hasil uji $\mathrm{p}<0,05$ yang menunjukkan hubungan signifikan antara ekspresi RANKL dengan terjadinya komplikasi. Hasil tersebut menunjukkan bahwa semakin kuat ekspresi RANKL maka semakin meningkatlah komplikasi yang terjadi.

Proporsi derajat destruksi tulang yang dihubungkan dengan umur terlihat pada gambar 4. Derajat destruksi tulang dikelompokkan menjadi derajat ringan, sedang, sampai dengan berat yang dihubungkan dengan kelompok umur. Hasil uji statistik menunjukkan hubungan yang tidak signifikan di mana $\mathrm{p}>0,05$.

Gambar 5 menjelaskan proporsi derajat destruksi tulang, yaitu dari derajat ringan, sedang, sampai dengan berat, yang dihubungkan dengan jenis kelamin. Hasil uji statistik menunjukkan hubungan tidak signifikan, di mana $\mathrm{p}>0,05$.

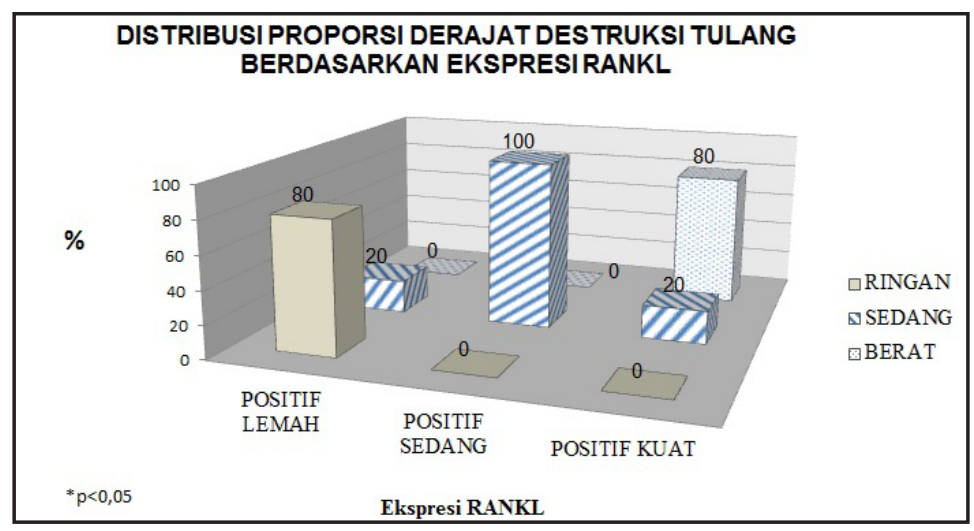

Gambar 2. Proporsi ekspresi RANKL yang dihubungkan dengan derajat destruksi tulang pada penderita OMSK.

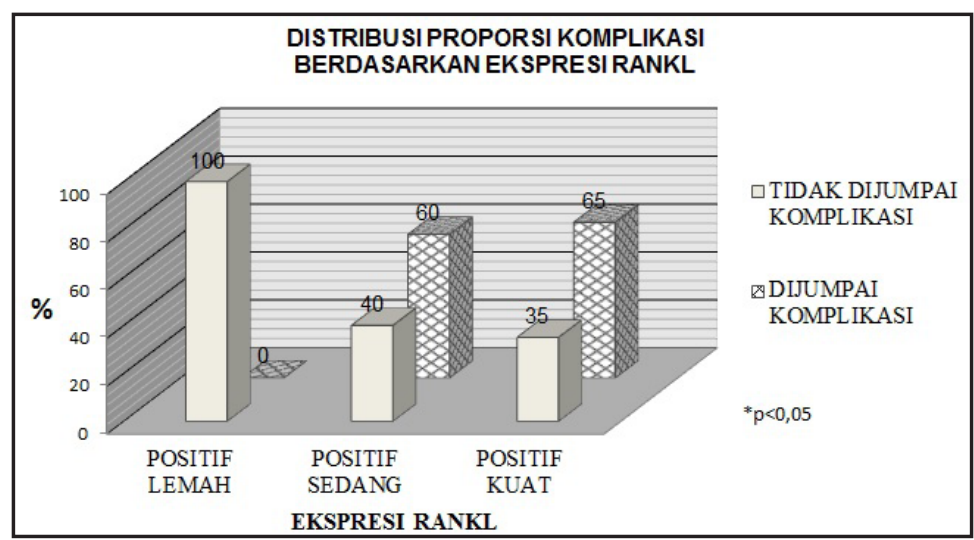

Gambar 3. Proporsi ekspresi RANKL yang dihubungkan dengan komplikasi pada penderita OMSK 


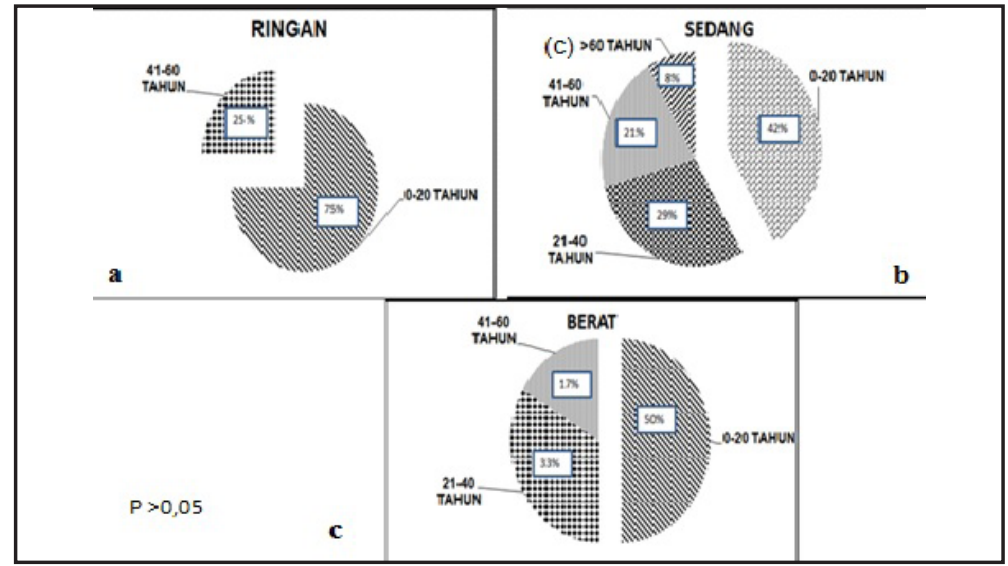

Gambar 4. Proporsi derajat destruksi tulang yang dihubungkan dengan umur. (a) derajat destruksi tulang ringan; (b) derajat destruksi tulang sedang; dan (c) derajat destruksi tulang berat

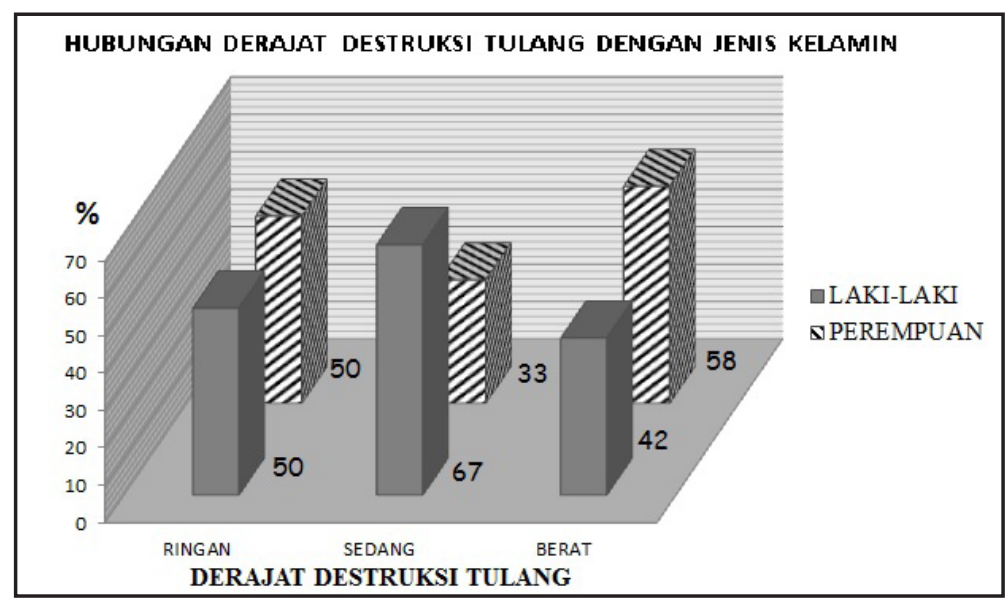

Gambar 5. Proporsi derajat destruksi tulang dihubungkan dengan jenis kelamin

\section{DISKUSI}

Pada OMSK tipe bahaya terjadi akumulasi sel debris dan keratinosit yang diinvasi oleh sel sistem imun termasuk sel Langerhans, sel-T, dan makrofag. Proses ini distimulasi oleh proliferasi epitel yang tidak seimbang, diferensiasi, maturasi keratinosit, dan pemanjangan apoptosis yang akhirnya terbentuk kolesteatoma. Migrasi sel digantikan oleh hiperplasia dalam kondisi inflamasi. Inflamasi yang mendorong proliferasi epitel berhubungan dengan peningkatan ekspresi enzim litik dan sitokin yang akan menstimulasi diferensiasi dan maturasi osteoklas atau dapat bereaksi pada matriks tulang, memaparkannya terhadap osteoklas. Hal ini dapat menyebabkan degradasi matriks ekstraselular tulang, sehingga terjadi erosi atau destruksi tulang yang menyebabkan komplikasi OMSK tipe bahaya. ${ }^{16}$

Aktivitas osteoklas pada inflamasi akan menyebabkan reabsorbsi tulang, di mana pembentukan osteoklas dari sel prekursor dikontrol oleh 2 sitokin esensial, yaitu RANKL dan Macrophage Colony Stimulating Factor (M-CSF). Pada keadaan normal, osteoblas memproduksi M-CSF dan RANKL untuk memulai pembentukan osteoklas dengan menarik reseptor-reseptor c-fms dan RANK. 
Sedangkan pada kondisi patologis, banyak sel yang terlibat untuk menghasilkan sitokinsitokin tersebut. Inhibitor yang penting pada proses tersebut yaitu osteoprotegrin (OPG), yang berkompetisi dengan RANK untuk RANKL. ${ }^{11,12}$

Pada penelitian ini dijumpai 40 subyek penderita OMSK tipe bahaya dengan kolesteatoma. Komplikasi yang paling banyak ditemukan adalah abses restroaurikula sebanyak 10 responden, diikuti dengan terjadinya fistel retroaurikula sebanyak 8 responden, kemudian sebanyak 7 responden mengalami paresis nervus fasialis, dan labirinitis sebanyak 5 responden. Meskipun abses otak hanya ditemukan pada 1 subyek, hal ini telah membuktikan variasi yang sangat luas dari komplikasi yang terjadi.

Komplikasi OMSK memang berbedabeda polanya. Viswanatha \& Naseeruddin ${ }^{1}$ di India menemukan komplikasi OMSK yang paling sering terjadi adalah abses lobus temporalis, yaitu pada 24 penderita $(33,3 \%)$, sedangkan komplikasi yang paling jarang terjadi adalah abses ekstradural dan abses lobus oksipitalis. Islam et a ${ }^{17}$ di Bangladesh mendapatkan komplikasi intratemporal OMSK tipe bahaya terbanyak adalah abses mastoid yaitu pada 11 penderita $(50 \%)$, sementara komplikasi intrakranial terbanyak adalah meningitis, yaitu pada 5 penderita $(83 \%)$.

Komplikasi kolesteatoma yang berbedabeda ini bisa terjadi akibat dari perbedaan destruksi terhadap struktur tulang di sekitar kolesteatoma, yang meliputi osikel, kapsul otik, kanalis nervus fasialis, segmen timpani, dan segmen mastoid. ${ }^{8}$

Pada penelitian ini, ekspresi RANKL yang paling banyak dijumpai adalah yang berada dalam kategori positif sedang, yaitu sebanyak 20 sampel. Kategori positif lemah sebanyak 5 sampel dan untuk kategori positif kuat sebanyak 15 sampel. Jika dihubungkan dengan derajat destruksi tulang, sebanyak
24 sampel ada pada kategori sedang dan 12 sampel berada dalam kategori derajat destruksi tulang yang berat, dan hanya 4 sampel termasuk dalam kategori ringan. Hasil distribusi ini berguna untuk mengetahui bagaimana hubungan ekspresi RANKL dengan derajat destruksi tulang. Setelah dilakukan uji statistik menggunakan uji Fisher diperoleh hasil yang signifikan antara ekspresi RANKL dengan derajat destruksi tulang, dengan $\mathrm{p}<0,05$. Sehingga terdapat hubungan yang sangat erat antara ekspresi RANKL dengan derajat destruksi tulang. Gambar 2 menunjukkan bahwa semakin kuat ekspresi RANKL maka derajat destruksi tulang dari kolesteatoma yang diperiksa akan semakin berat.

Miyasato dkk ${ }^{12}$ menemukan hasil ekspresi RANKL meningkat pada pemeriksaan imunohistokimia dari kolesteatoma. Chung ${ }^{13}$ menemukan adanya overekspresi dari hasil pemeriksaan RANKL pada kolesteatoma dibandingkan dengan epitel kulit normal.

Pada penelitian ini dilakukan uji Fisher untuk melihat hubungan ekspresi RANKL dengan terjadinya komplikasi. Gambar 3 menjelaskan mengenai proporsi ekspresi RANKL yang dihubungkan dengan komplikasi dengan hasil uji $\mathrm{p}<0,05$, terlihat dengan jelas hubungan yang signifikan antara ekspresi RANKL dengan terjadinya komplikasi. Semakin kuat ekspresi RANKL maka komplikasi yang terjadi semakin meningkat.

Penelitian ini mendapati bahwa destruksi tulang yang terjadi dapat mengenai siapa saja, tidak dibatasi kelompok umur (gambar 4). Viswanatha \& Naseeruddin ${ }^{1}$ mendapatkan mayoritas penderita OMSK adalah pada kelompok umur 0-20 tahun yaitu sebanyak 36 penderita $(50,0 \%)$. $\operatorname{Kumar}^{18}$ mendapatkan kelompok usia yang terbanyak ditemukan pada kategori 25-35 tahun dengan persentase $40 \%$. Aquino $\mathrm{dkk}^{20}$ menjelaskan bahwa penderita OMSK yang dewasa lebih banyak ditemukan dibanding dengan anak-anak 
karena penderita OMSK ini cenderung membiarkan penyakitnya sampai akhirnya mencari pengobatan lebih lanjut. Selain itu, penyakit OMSK tipe bahaya ini cenderung mengenai pasien-pasien dengan kelas ekonomi rendah. Akan tetapi, tidak ditemukan adanya hubungan yang bermakna dari perbedaan kelompok umur dengan terjadinya destruksi tulang.

Pada penelitian ini didapati bahwa destruksi tulang dapat terjadi pada laki-laki maupun perempuan (gambar 5).

Chole \& Nason ${ }^{8}$ menyebutkan pada beberapa penelitian, laki-laki lebih banyak menderita OMSK, namun tidak terdapat penelitian yang membuktikan adanya hubungan antara OMSK dengan jenis kelamin. Maka dengan demikian, destruksi tulang yang terjadi dapat mengenai siapa saja tidak tergantung dari jenis kelamin dan umur. Namun, destruksi tulang tersebut bergantung dari kondisi infeksi, serta inflamasi yang akan memfasilitasi pertumbuhan kolesteatoma telinga tengah serta absorpsi tulang. ${ }^{11,12}$

Pada penelitian ini gejala dari penyakit OMSK yang menyerang bervariasi mulai dari telinga berair, gangguan pendengaran, bengkak di belakang telinga, lubang di belakang telinga, mulut mencong, sakit kepala, hingga vertigo. Pada penelitian yang dilakukan oleh Siregar ${ }^{7}$ di Rumah Sakit Umum Pusat H. Adam Malik Medan, ditemukan sebanyak 73 penderita $(61,34 \%)$ mengeluhkan telinga berair. Serupa dengan Aquino dkk, ${ }^{19}$ didapati gejala klinis terbanyak pada penderita kolesteatoma adalah telinga berair sebanyak $66,5 \%$ penderita. Terkadang pasien tidak merasa bahwa telinganya berair karena jumlah cairannya sedikit, sehingga tidak muncul di liang telinga. Jumlah cairan yang sedikit mengering pada bagian ujung medial liang telinga dan membentuk krusta. Namun bila ditanya, pasien sering menyatakan terdapat riwayat otore sewaktu kecil. ${ }^{20}$
Infeksi telinga tengah kronis terdiri dari dua tipe, yaitu benigna dan maligna atau tipe bahaya yang ditandai dengan adanya kolesteatoma. Adanya kolesteatoma dapat menstimulasi lipopolisakarida dan mengakibatkan terjadinya peningkatan ekspresi RANKL, sehingga dijumpai osteoklas yang lebih banyak dan pada akhirnya absorbsi tulang juga meningkat. Hal ini menyebabkan destruksi tulang juga mengalami peningkatan. Ekspresi RANKL yang meningkat, menyebabkan absorbsi tulang akan meningkat pula, dan akhirnya mengakibatkan meningkatnya destruksi tulang. ${ }^{8}$

Ekspresi RANKL yang dijumpai memiliki 3 kategori yaitu positif lemah, positif sedang, dan positif kuat (gambar 1). Pada gambar 1 bisa kita lihat intensitas pewarnaannya dan jumlah sel yang terwarnai. Sementara itu belum ada penelitian di Indonesia yang bertujuan mencari ekspresi RANKL pada kolesteatoma yang terdapat pada penderita OMSK tipe bahaya. Namun, Miyasato $^{12}$ menemukan adanya peningkatan ekspresi RANKL pada pemeriksaan kolesteatoma terhadap penderita OMSK tipe bahaya melalui pemeriksaan imunohistokimia. Chung ${ }^{13}$ di China yang menemukan adanya overekspresi RANKL pada kolesteatoma dari penderita OMSK tipe bahaya.

Kesimpulan dari penelitian ini ialah terdapat hubungan yang signifikan antara ekspresi RANKL dengan derajat destruksi tulang, dan komplikasi. Namun, tidak ada hubungan antara derajat destruksi tulang dengan kelompok umur dan jenis kelamin. Saran yang perlu dilakukan adalah penelitian lanjutan mengenai peran penghambat RANKL pada penyakit OMSK tipe bahaya, guna menurunkan derajat destruksi tulang akibat kolesteatoma pada penyakit OMSK tipe bahaya. Perlu juga dilakukan penelitian lanjutan mengenai korelasi RANKL dengan sitokin pro inflamasi lainnya pada 
kolesteatoma, guna mencegah terjadinya destruksi tulang yang lebih luas akibat kolesteatoma pada penyakit OMSK tipe bahaya ini.

\section{DAFTAR PUSTAKA}

1. Vishwanath S, Mukhopadhyay C, Mukhopadhyay, Prakash R, Pillai S, Pujary K, et al. Chronic suppurative otitis media: Optimizing initial antibiotic therapy in a tertiary care setup. Indian journal otolaryngol head neck surgery. 2012; 64(3):285-9.

2. Orji, FT. A survey of the burden of management of chronic suppurative otitis media in developing country. Annals of Medical and Health Sciences Research. 2013; 3(4):598-601.

3. World Health Organization. Chronic suppurative otitis media. Burden of Illness and management options geneva. Switzerland: WHO. 2004; p 13-9.

4. Wulandari, Y. Perbedaan kadar inerleukin 1- $\alpha$ serum darah vena antara penderita OMSK tipe jinak dan tipe bahaya. Tesis. Surakarta: Pascasarjana Universitas Sebelas Maret; 2010. p. 1-79.

5. Yammin LH, Soemantri JB, Lukmantya. Laporan Penelitian: Hubungan otitis media supuratif kronis disertai kolesteatom dengan gangguan pengecapan. Oto Rhino Laryngologica Indonesiana. 2013; 43(1):113.

6. Siregar, DR. Profil penderita otitis media supuratif kronis (OMSK) tipe bahaya di RSUP. H. Adam Malik Medan Tahun 2006 -2010. Tesis. Medan: Pascasarjana Universitas Sumatera Utara; 2013. p.567571.

7. Lee KJ. CSOM with or without cholesteotoma. In: Essential otolaryngology: Head and neck surgery. Connecticut: Mc Graw Hill; 2003. p.484-6.
8. Chole DI, Nason, R. Chronic otitis media and cholesteatoma. In: JB Snow \& PA Wackyym (eds), Ballenger's Otorhinolaryngology Head And Neck Surgery. Connecticut: BC Decker Inc; 2009. p. 217-27.

9. Vitale RF, Ribeiro, FA. The role of tumor necrosis factor-alpha (TNF-alpha) in bone resorption present in middle ear cholesteatoma. Braz J Otorhinolaryngol. 2007; 73(1):117-21

10. Wright $T$, Valentine P. The anatomy and embryology of the external and middle ear. In: M Gleeson (ed), Scott-Brown`s Otorhinolaryngology, Head and Neck Surgery. London: Edward Arnold Ltd; 2008. p. 3105-25.

11. Kuczwoski J, Pawelczyk T, Bakowska A, Narozny W, Mikaszewski B, Expression pattern of Ki-67 and telomerase activity in middle ear. 2007. p 204-7.

12. Miyasato $\mathrm{M}$, Takeno S, Hirakawa $\mathrm{K}$. Expression of RANKL and proliferation abilities of cultured human middle ear cholesteatoma epithelial cells, Hiroshima. J Med Sci. 2013; 62(1):1-6.

13. Chung. The expression of receptor activator nuclear kappa B ligand and osteoprotegerin in cholesteatoma. Chinese. 2008; 22(3):293-5.

14. Kuczkowski J, Kobierska-Gulida G, Izycka-Swieszewska E, Potocka M, Mikaszewski B, Sierszeń W. Molecular control of bone resorption in chronic otitis media with cholesteatoma. Otolaryngol Pol. 2010; 64(4):219-24.

15. Jeong J, Pork C, Tae K, Lee S, Shin D, Kim $\mathrm{K}$, et al. Expression of RANKL and OPG in middle ear in cholesteatoma ear. The Laryngoscope. 2006; 116(7):1180-4.

16. Frickmann H, Zautner AE. Cholesteatoma - a potential consequence of chronic middle ear inflammation. Otolaryngology. $2012 ; 5: 1-8$. 
17. Islam R, Taous A, Hossain M, Ekramuddaula AFM, Islam MS. Comparative study of tubotympanic and atticoantral variety of chronic suppurative otitis media, Bangladesh. Journal Otolaryngology. 2010; 16(2):113-9.

18. Kumar S, Aqil S, Dahar A. Clinical markers of cholesteatoma. Journal of Otorhinolaryngology. 2011; 9(3):138-40.
19. Aquino, Filho NAC, Aquino JNP. Epidemiology of middle ear and mastoid cholesteatomas, study of 1146 cases. Brazillian Journal of Otorhinolaryngology. 2011; 77(3):1-11.

20. Browning GG, Merchant SN, Kelly G, Swan IRC, Canter R, McKerrow WS. Chronic otitis media. In: M. Gleeson (ed), Scott-Brown`s Otorhinolaryngology, Head and Neck Surgery. London: Edward Arnold Ltd. 2008. p. 3395-442. 